\title{
AIRLINE SERVICE FAILURE AND RECOVERY: THE IMPACT OF RELATIONSHIP FACTORS ON CUSTOMER SATISFACTION
}

\author{
Chi-Ruey Jeng ${ }^{1}$
}

Shu-Te University, Kaohsiung, Taiwan, R.O.C.

\begin{abstract}
In aviation industries, service failure during the service delivery process is foreseeable and leads to passenger complaints, which therefore presents the perfect opportunity for airlines to improve their service process and quality and examine their internal organization. Concurrently, the quality of the service recovery measures reflects the ability of airlines to respond to and handle traveler complaints. By rectifying service failures, airlines can enhance traveler satisfaction toward airlines services, thereby generating loyal customers who would engage in word-of-mouth marketing. This study aims to do examine the relationship between service failure, service recovery and passenger's satisfaction with service recovery types, employee prompt handling, and service recovery efficiency. The questionnaires used in this study consisted of three sections: (1) Customers' perception of the service recovery types; this section entails using passengers' subjective perceptions to evaluate the service recovery types adopted by the airlines when handling flight delay situations. (2) Customers' perception of the airlines employee's prompt handling; the traveler's subjective perception to evaluate the airlines employees' direct responses to flight delays. (3) Customers' perception of the problem-solving efficiency; this section involves using the passengers' subjective perception to evaluate the overall flight delay recovery progress. The traveler characteristics were divided into 'passenger attributes' and 'traveling attributes' and their relationships with service recovery types, employee's prompt handling, and problem solving efficiency were examined. The research results showed that passenger attributes demonstrated no significant differences with the three dimensions (i.e., service recovery types, employee's prompt handling, and problem solving efficiency). However, concerning traveling attributes, 'purpose of travel' and 'flight delay experience' demonstrated significant differences with the three dimensions.
\end{abstract}

Keywords: service failure, service recovery, satisfaction

Dr Chi-Ruey Jeng is Assistant Professor of the department of Leisure \& Tourism Management at Shu-Te University in Kaohsiung, Taiwan. His research focuses on air transport and tourism management. E-mail: charles5@stu.edu.tw 


\section{INTRODUCTION}

Satisfaction of customers is the most priority for all service industries and the civil aviation industry is no exclusion. Due to the characteristics of service, such as intangibility, inseparability and variability, failures are inevitable. However, defects or dissatisfaction in any encounter during service delivery may cause customer dissatisfaction (Lapre, 2011), which leads to customers' negative behavioral responses (Zeelenberg \& Pieters, 2004). Service failure and the subsequent complaints from customers are a likely occurrence over a product/service lifetime and the rapid, effective handling of these has proven to be vital in maintaining customer satisfaction and loyalty (Bamford \& Xystouri, 2005). Organizations that avoid service failure fare lot better than organizations focusing on service recovery after failure (McCollough et al., 2000). Thus, when service failure happens, service providers must immediate take necessary recoveries to retain their customers.

Service failures in airline industry such as flight delays are inevitable. In airline industry, external factors beyond the immediate control frequently can cause service failure, such as flight delay or cancellation due to air traffic congestion, or a failure in another airport where the airline's aircraft are involved. In addition, many airports around the world face serious delay problems as a result of imbalanced demand of flights and available capacity after air transport liberalization. Boshoff (1997) surveyed 540 travellers, presenting them with a constantly negative service situation (a missed flight connection caused by flight delay) and looked for the most successful recovery strategies. They were: a fast response by the highest possible person in terms of seniority; a fast response accompanied by full refund plus some amount of compensation; a large amount of compensation provided by a high-ranking manager.

Bamford \& Xystouri (2005) also mention that, the importance of service recovery reinforces the need for organizations to find approaches that are effective in both identifying service failure and in developing strategies to recover successfully. Service recovery should be the cornerstone of a customer satisfaction strategy. According to Weber and Sparks (2004), ineffective service recovery may lead to a negative word-of-mouth. Xu \& Li (2016) suggest that service providers' ability to understand their customers' views of service failure can be the antecedent for developing an appropriate recovery processes and providing more robust service operations. Therefore, this study aims to do examine the relationship between service failure, service recovery and passenger's satisfaction with service recovery types, employee 
prompt handling, and service recovery efficiency.

\section{LITERATURE REVIEW}

In general, to increase customer satisfaction, companies in the service industry can adopt two major strategies: active or passive strategies. Active strategies are focused on minimizing the gaps of inconsistencies before the events occur (Churchill \& Suprenant, 1982; Oliver, 1980; Oliver \& DeSarbo, 1988). Passive strategies are concentrated on providing timely service recovery when service failures occur. Fisk et al. (1993) argue that due to the unique nature of services (specifically, coproduction and the inseparability of production and consumption) it is impossible to ensure $100 \%$ error-free service. According to Bitner et al. (1990) asserted that service failure occurs when the service providers are unable to meet the customers' service demands or when the core services provided failed to satisfy the customers' minimum expectation.

This corporate service behavior (from first to last service encounter) is considered by the customers to be unsatisfactory. Therefore, service failure can occur any time during the customer-service provider interaction. And the types of service failure were proposed by Bitner et al. (1990), who investigated service failure from the service encounter perspective and summarized three major failure types based on 700 case projects regarding airlines, hotels, and restaurant industries: (a) customer dissatisfaction resulting from service delivery system failure; (b) customer dissatisfaction resulting from inability to respond to customer demands; and (c) customer dissatisfaction resulting from poor employee conduct.

Airlines are susceptible to service failures due to the nature of the service process they apply in service delivery (Steyn et al., 2011). Previous research has indicated a number of causes leading to service failures in the airline industry, including flight cancellations, diversions or delays, attitudes of ground and cabin staff, strikes, reservation problems and overbooking of flights (Bamford \& Xystouri, 2005). As a result, it was anticipated that most airline passengers would find manipulations regarding recovery expectations, recovery performance, and justice realistic and believable. In airline companies, service failure during the service delivery process is completely inevitable and leads to traveler complaints. Service recovery strategy is among the most efficient ways to alleviate the negative outcome caused by service failure (Craighead et al., 2004). Service recovery actions also provide an opportunity for service providers to implement recovery actions and turn angry and complaining customers into loyal customers (Lapre, 2011). Concurrently, the quality of the recovery procedures reflects the airlines' 
ability to respond and handle passenger complaints. By rectifying the service failures, airlines can enhance the passenger's satisfaction toward airlines services, thereby generating loyal customers who would engage in word-of-mouth marketing. The most common airlines service failure is flight delay, which leads to financial losses for both the airlines and the passengers. For most passengers, when facing a flight delay or cancellation, will have no choice but to seek redress as canceling the trip is not an option (McColloug et al., 2000). For passengers, the effects of flight delays may differ based on the cause of the delay and the purpose of travel. Nevertheless, customer rights and interests will inevitably be negatively affected.

According to Hart et al. (1990), Johnston \& Hewa (1997), and Maxham III (2001), service recovery refers to the actions taken by the service providers to reduce or recover the losses suffered by the customers during the service delivery process. When service failure occurs, customers believe that companies should take actions to compensate them, regardless of effects of the recovery measures (Cheng, 2002). Related studies on air transport have shown that a satisfactory service recovery measure promotes post-recovery satisfaction of customers. Poor service recovery leads to the customers' repeated bias in their service expectations. When this occurs, basic services provided and service recovery efforts attempted by the companies would be proven ineffective (McCollough et al., 2000). Therefore, providing a satisfactory service recovery compared with poor recovery measures is the only opportunity to enhance customer satisfaction when service failure occurs. Effective service recovery has a positive impact on post-recovery word-of-mouth communication (Schoefer \& Ennew, 2004).

\section{STUDY METHODS}

\subsection{Study Framework \& Hypotheses}

Based on the research objectives mention above, this study examined the relationship of customer post-recovery satisfaction with traveler characteristics (passenger attributes and traveling attributes), service recovery types, prompt handling and problem solving efficiency, which comprised the study framework.

When service failure occurs, the recovery processes adopted by companies and the time/speed adopted to implement these processes have an undeniable effect on customer satisfaction. Therefore, service recovery types, prompt handling and problem 
solving efficiency play a critical role in company operation. Moreover, passenger attributes also have an effect on customer satisfaction. The previous literature shows that difference types of service recovery strategies to have a significant impact on customer post-recovery satisfaction (Wirtz \& Mattila, 2004; Wen \& Chi, 2013). Liao (2007) argues that prompt handling refers to service employees' quick response to a customer complaint. Response speed has been linked to customer satisfaction in the service recovery literature. Wirtz \& Mattila (2004) also suggest that a fast recovery would be seen by consumers as a cue for a service provider being efficient and generally offering good quality service. According the above literature, the hypotheses of this research are listed as follows:

H1: Passenger attributes positive effect on post-recovery satisfaction

H1-1: Service recovery types positive effect post-recovery satisfaction for different passenger attributes

H1-2: Prompt handling positive effect post-recovery satisfaction for different passenger attributes

H1-3: Problem solving efficiency positive effect post-recovery satisfaction for different passenger attributes

$\mathrm{H} 2$ : Traveling attributes positive effect on post-recovery satisfaction

H2-1: Service recovery types positive effect post-recovery satisfaction for different traveling attributes

H2-2: Prompt handling positive effect post-recovery satisfaction for different traveling attributes

H2-3: Problem solving efficiency positive effect post-recovery satisfaction for different traveling attributes

\subsection{Questionnaire Design \& Data Collection}

In this study, questionnaires were implemented for conducting the investigation. The questionnaires consisted of open-ended questions to obtain the responses of the respondents when encountering flight delays. The questionnaire was divided into five parts, which were used for obtaining the respondents' demographic information, travelling conditions, and their satisfaction with the service recovery measures, employee responses, and recovery efficiency.

The questionnaire was designed with a 7-point Likert scale for measurement, and the 
scores were judged based on the passengers' subjective perception. The degree of importance was identified as 'extremely unimportant, unimportant, slightly unimportant, neutral, slightly important, important, and extremely important', which were allocated a score of $1,2,3,4,5,6$, and 7, respectively. A higher score indicated greater importance.

The study respondents were customers who had travelled on international flights. The questionnaires were disseminated to respondents found in the Arrival and Departure Hall at the Kaohsiung International Airport. They respondents were asked to complete the questionnaires on site. A total of 450 questionnaires were disseminated and returned, yielding a questionnaire return rate of $100 \%$. After removing 84 incomplete questionnaires, 366 valid questionnaires were obtained, yielding a response rate of $81.3 \%$.

\subsection{Data Analysis Methods}

This study employed the SPSS statistics software to analyze the valid questionnaires for testing the study hypotheses. The statistical methods included the following:

(1) Reliability analysis: used to measure the reliability of the data and items such as recovery measures, employee responses, and service recovery efficiency. Cronbach's a was used as the discriminant value.

(2) Descriptive analysis: frequency distribution, percentage, standard deviation, and ranking were used to describe the data distribution of the variables traveler characteristics, recovery measures, employee responses, and service recovery efficiency.

(3) $T$ test: used to determine whether customer satisfaction with the service recovery measures, employee responses, and service recovery efficiency differs significantly between customers of different sexes and for passengers who have and have not had flight delay experiences.

(4) Single-factor ANOVA: adopted to determine whether customer satisfaction with the service recovery measures, employee responses, and service recovery efficiency differs significantly for customers of different ages, education levels, occupations, monthly incomes, numbers of flights taken, and travel purposes.

\section{STUDY RESULTS}

\subsection{Reliability Analysis}

The reliability of this research shows as Table 1 , the Cronbach's a values are 0.903 , 
0.937, and 0.871 for the 'Service recovery types', 'Prompt handling', and 'Problem solving efficiency', respectively. The Cronbach's a value for the overall item in the questionnaire was 0.957 , indicating overall content consistency and high reliability.

Table 1 - Reliability Analysis

\begin{tabular}{|l|c|c|}
\hline & questions & $\begin{array}{c}\text { Cronbach's a } \\
\text { values }\end{array}$ \\
\hline Service recovery types & 8 & 0.903 \\
\hline Prompt handling & 6 & 0.937 \\
\hline Problem solving efficiency & 4 & 0.871 \\
\hline Total & 18 & 0.957 \\
\hline
\end{tabular}

\subsection{Descriptive Analysis}

This descriptive analysis including seven variables shows as Table 2, which were sex, age, occupation, education level, monthly income, purpose of travel, and have or have not had a delayed flight experience. Concerning service recovery for flight delays, three dimensions that consisted of service recovery types (8 questions), prompt handling (6 questions), and problem solving efficiency (4 questions) were used. Next, the means and standard deviations from the descriptive analysis were used to examine customer satisfaction.

The questionnaire analysis showed that female respondents (56.6\%) are more than male respondents. The traveler groups that accounted for the highest proportions of the other variables are listed as follows: (a) age: 21 to 30 (41.5\%); (b) education level: university degree (51.7\%); (c) occupation: service industry $(29.6 \%)$; (d) monthly income: NT\$20,000 to NT\$40,000 (44.8\%); (e) purpose of travel: tourism (73\%); (f) airline chosen: China Airlines (44.8\%); (g) flight delay experience: yes (54.9\%). 
Table 2 - Descriptive Analysis

\begin{tabular}{|c|c|c|}
\hline Variables & Counts & $\%$ \\
\hline \multicolumn{3}{|c|}{ Sex } \\
\hline Male & 159 & $43.4 \%$ \\
\hline Female & 207 & $56.6 \%$ \\
\hline \multicolumn{3}{|c|}{ Age } \\
\hline Below 20 & 23 & $6.3 \%$ \\
\hline 20 to 30 & 152 & $41.5 \%$ \\
\hline 31 to 40 & 124 & $33.9 \%$ \\
\hline 41 to 50 & 50 & $13.7 \%$ \\
\hline 51 to 60 & 15 & $4.1 \%$ \\
\hline 61or above & 2 & $0.5 \%$ \\
\hline \multicolumn{3}{|c|}{ Education level } \\
\hline Junior high school or below & 2 & $0.5 \%$ \\
\hline High school/vocational school & 59 & $16.1 \%$ \\
\hline Vocational college & 64 & $17.5 \%$ \\
\hline University & 189 & $51.7 \%$ \\
\hline Graduate school or above & 52 & $14.2 \%$ \\
\hline \multicolumn{3}{|c|}{ Occupation } \\
\hline Civil servants & 14 & $3.8 \%$ \\
\hline Businessmen & 34 & $9.3 \%$ \\
\hline Military and police officers & 4 & $1.1 \%$ \\
\hline Teachers & 18 & $4.9 \%$ \\
\hline Freelancers & 48 & $13.1 \%$ \\
\hline Service industry workers & 108 & $29.6 \%$ \\
\hline Housekeepers & 19 & $5.2 \%$ \\
\hline Students & 62 & $16.9 \%$ \\
\hline Other & 59 & $16.1 \%$ \\
\hline \multicolumn{3}{|c|}{ Monthly Income } \\
\hline NT $\$ 20,000$ or below & 78 & $21.3 \%$ \\
\hline NT $\$ 20,000$ to NT $\$ 40,000$ & 164 & $44.8 \%$ \\
\hline NT $\$ 40,000$ to NT $\$ 60,000$ & 79 & $21.6 \%$ \\
\hline NT $\$ 60,000$ to NT $\$ 80,000$ & 21 & $5.7 \%$ \\
\hline NT $\$ 80,000$ to NT $\$ 100,000$ & 12 & $3.3 \%$ \\
\hline NT $\$ 100,000$ or above & 12 & $3.3 \%$ \\
\hline \multicolumn{3}{|c|}{ Purpose of travel } \\
\hline Business trip & 48 & $13.0 \%$ \\
\hline Tourism & 267 & $73.0 \%$ \\
\hline Visiting relatives & 34 & $9.3 \%$ \\
\hline Study & 4 & $1.1 \%$ \\
\hline Other & 13 & $3.6 \%$ \\
\hline \multicolumn{3}{|c|}{ Flight delay experience } \\
\hline Yes & 201 & $54.9 \%$ \\
\hline No & 165 & $45.1 \%$ \\
\hline
\end{tabular}


1. Importance of Service recovery types

Regarding service recovery types, the analysis results showed that the item 'airlines' assistance to arrange a new flight or other means of transport' scored the highest degree of importance (5.965), which was followed by 'airlines offering monetary compensation or refund' (5.902). The item 'airlines apologizing in person' demonstrated the least degree of importance (5.514).

2. Importance of Prompt handling

Concerning prompt handling, the analysis results showed that the item 'employees taking the initiative to explain the recovery progress' scored the highest degree of importance (6.137), which was followed by 'employees demonstrating an sincere attitude' (6.096). The item 'ability to pacify traveler's discontent' demonstrated the least degree of importance (5.910).

3. Importance of Problem solving efficiency

Regarding the problem-solving efficiency, the item 'the service recovery time was longer than what I expected' scored the highest degree of importance (5.661), which was followed by 'airlines' recovery result compensated for the time I had lost' (5.765). The item 'airlines' recovery result was able to meet my demand' demonstrated the least degree of importance (5.910).

\subsection{The Effects of Traveler Characteristics on Recovery Measures, Employee} Responses, and Service Recovery Efficiency

This section examines the differences in the customers' satisfaction with the various service recovery types, prompt handling and problem solving efficiency based on different sex, age, education level, occupation, monthly income, purpose of travel, and flight delay experience.

The results show that customer satisfaction presented no significant differences between those of different personal attributes, e.g. sexes, ages, education levels, occupations, and monthly incomes. However, significant differences were observed for purposes of travel and flight delay experience.

Table 3 - ANOVA on the Effects of Personal Attributes on Service Recovery Measures

\begin{tabular}{lccc}
\hline Variables & $\begin{array}{l}\text { Service recovery } \\
\text { types (mean) }\end{array}$ & $\begin{array}{l}\text { Prompt handling } \\
\text { (mean) }\end{array}$ & $\begin{array}{l}\text { Problem solving } \\
\text { efficiency (mean) }\end{array}$ \\
\hline $\begin{array}{l}\text { Sex } \\
\text { Male }\end{array}$ & 5.7602 & 5.9937 & 5.7846 \\
\hline
\end{tabular}




\begin{tabular}{|c|c|c|c|}
\hline Female & 5.8050 & 6.0411 & 5.8350 \\
\hline $\mathrm{T}$ value & 0.403 & 0.576 & 0.062 \\
\hline Significance level & 0.526 & 0.448 & 0.804 \\
\hline \multicolumn{4}{|l|}{ Age } \\
\hline Below 20 & 5.7717 & 6.1232 & 5.8804 \\
\hline 20 to 30 & 5.7738 & 6.0044 & 5.7748 \\
\hline 31 to 40 & 5.8317 & 6.0175 & 5.8387 \\
\hline 41 to 50 & 5.6950 & 5.9267 & 5.7050 \\
\hline 51 to 60 & 5.7833 & 6.2778 & 6.1333 \\
\hline 61or above & 6.2500 & 6.6667 & 6.6250 \\
\hline F value & 0.243 & 0.500 & 0.701 \\
\hline Significance level & 0.943 & 0.776 & 0.623 \\
\hline \multicolumn{4}{|l|}{ Education level } \\
\hline $\begin{array}{l}\text { Junior high school } \\
\text { or below }\end{array}$ & 6.2500 & 6.5833 & 6.5000 \\
\hline $\begin{array}{l}\text { High } \\
\text { school/vocational } \\
\text { school }\end{array}$ & 5.7987 & 5.9294 & 5.7331 \\
\hline Vocational college & 5.7539 & 6.1380 & 5.9063 \\
\hline University & 5.7493 & 6.0000 & 5.7886 \\
\hline $\begin{array}{l}\text { Graduate school or } \\
\text { above }\end{array}$ & 5.9231 & 6.0321 & 5.8510 \\
\hline F value & 0.470 & 0.514 & 0.470 \\
\hline Significance level & 0.758 & 0.726 & 0.758 \\
\hline \multicolumn{4}{|l|}{ Occupation } \\
\hline Civil servants & 5.7054 & 6.0357 & 5.8036 \\
\hline Businessmen & 5.5662 & 5.9216 & 5.8235 \\
\hline $\begin{array}{l}\text { Military and police } \\
\text { officers }\end{array}$ & 5.9688 & 6.5833 & 6.0625 \\
\hline Teachers & 5.5208 & 5.6111 & 5.5417 \\
\hline Freelancers & 5.7526 & 5.9792 & 5.6406 \\
\hline $\begin{array}{l}\text { Service industry } \\
\text { workers }\end{array}$ & 5.9352 & 6.1497 & 5.9190 \\
\hline Housekeepers & 6.0658 & 6.2281 & 5.9868 \\
\hline Students & 5.8367 & 6.1210 & 5.8074 \\
\hline Other & 5.6081 & 5.7853 & 5.7712 \\
\hline F value & 1.245 & 1.395 & 0.555 \\
\hline Significance level & 0.272 & 0.197 & 0.815 \\
\hline \multicolumn{4}{|l|}{ Monthly Income } \\
\hline $\begin{array}{l}\text { NT } \$ 20,000 \text { or } \\
\text { below }\end{array}$ & 5.8029 & 6.0897 & 5.8141 \\
\hline $\begin{array}{l}\text { NT } \$ 20,000 \text { to } \\
\text { NT } \$ 40,000\end{array}$ & 5.8438 & 6.0549 & 5.8313 \\
\hline $\begin{array}{l}\text { NT } \$ 40,000 \text { to } \\
\text { NT } \$ 60,000\end{array}$ & 5.7642 & 6.0190 & 5.8196 \\
\hline $\begin{array}{l}\text { NT } \$ 60,000 \text { to } \\
\text { NT } \$ 80,000\end{array}$ & 5.5536 & 5.6429 & 5.6310 \\
\hline $\begin{array}{l}\text { NT } \$ 80,000 \text { to } \\
\text { NT } \$ 100,000\end{array}$ & 5.7604 & 6.0000 & 5.8958 \\
\hline NT $\$ 100,000$ or & 5.4479 & 5.7917 & 5.7500 \\
\hline
\end{tabular}


above

$F$ value

0.676

0.826

0.160

Significance level

0.642

0.532

0.977

$* * p \leq .05$

\section{Table 4 - ANOVA on the Effects of Traveling attributes on Service Recovery} Measures

\begin{tabular}{lccc}
\hline Variables & $\begin{array}{l}\text { Service recovery } \\
\text { types (mean) }\end{array}$ & $\begin{array}{l}\text { Prompt handling } \\
\text { (mean) }\end{array}$ & $\begin{array}{c}\text { Problem solving } \\
\text { efficiency (mean) }\end{array}$ \\
\hline Purpose of travel & & 5.4714 & 5.4714 \\
Business trip & 5.4714 & 5.9471 & 5.9471 \\
Tourism & 5.9471 & 5.2132 & 5.2132 \\
Visiting relatives & 5.2132 & 5.9375 & 5.9375 \\
Study & 5.9375 & 5.0769 & 5.0769 \\
Other & 5.0769 & 3.964 & 2.685 \\
F value & 8.692 & $0.004^{* *}$ & $0.031^{* *}$ \\
Significance level & $0.000^{* *}$ & & \\
Flight delay experience & & 5.9050 & 5.8053 \\
Yes & 5.6831 & 6.1596 & 5.8273 \\
No & 5.9045 & 23.185 & 7.609 \\
T value & 12.512 & $0.000^{* *}$ & $0.006^{* *}$ \\
Significance level & $0.000^{* *}$ & & \\
\hline
\end{tabular}

$* * p \leq .05$

\section{CONCLUSION AND RECOMMENDATIONS}

\subsection{Conclusion}

By using empirical analyses, this study investigated the relationship of customer post-recovery satisfaction with traveler characteristics (passenger attributes and traveling attributes), service recovery types, prompt handling and problem solving efficiency. The test results of study hypotheses are organized and shown in Table 5 as below.

This study divided traveler characteristics into 'passenger attributes' and 'traveling attributes' and examined whether customer satisfaction with service recovery differed significantly for customers of varying passenger attributes and travelling attributes. Flight delays were used as the service failure setting and the relationship between customer post-recovery satisfaction and the three dimensions (i.e., service recovery types, prompt handling and problem solving efficiency) were investigated.

The analysis showed that the statistical values of the items for service recovery types were similar, indicating that all the passengers considered recovery types crucial. Of all the recovery types, the item 'airlines' assistance to arrange a new flight or other means of transport' achieved the highest score whereas the item 'airline apologizing in person' 
achieved the lowest score. When flight delays occur, the ability of airlines to promptly arrange a new flight or other means of transportation for passengers to reach their destinations is highly essential. Apologies in person without concrete, tangible recovery measures result in commotion and agitation among customers because they have no knowledge regarding the subsequent progresses.

Table 5 - Study hypotheses and test results

\begin{tabular}{|l|l|}
\hline \multicolumn{1}{|c|}{ Study hypotheses } & Results \\
\hline $\begin{array}{l}\text { H1-1: Service recovery types positive effect post-recovery satisfaction for } \\
\text { different passenger attributes }\end{array}$ & False \\
\hline $\begin{array}{l}\text { H1-2: Prompt handling positive effect post-recovery satisfaction for } \\
\text { different passenger attributes }\end{array}$ & False \\
\hline $\begin{array}{l}\text { H1-3: Problem solving efficiency positive effect post-recovery } \\
\text { satisfaction for different passenger attributes }\end{array}$ & False \\
\hline $\begin{array}{l}\text { H2-1: Service recovery types positive effect post-recovery satisfaction for } \\
\text { different traveling attributes }\end{array}$ & True \\
\hline $\begin{array}{l}\text { H2-2: Prompt handling positive effect post-recovery satisfaction for } \\
\text { different traveling attributes }\end{array}$ & True \\
\hline $\begin{array}{l}\text { H2-3: Problem solving efficiency positive effect post-recovery } \\
\text { satisfaction for different traveling attributes }\end{array}$ & True \\
\hline
\end{tabular}

In addition, the results showed that the statistical values of items for employee prompt handling were similar, indicating that all the passengers considered employees' prompt handling is very important. Of the entire employee prompt handling, the item 'employees taking the initiative to explain the recovery progresses achieved the highest score whereas the item 'ability to pacify traveler's discontent' achieved the lowest score. When flight delays occur, what passengers are concerned with are the cause of the delay and the airlines' plans, such as 'the scheduled departure time of the next flight', and 'whether other means of transport or meals are provided'. If the airlines only focus on pacifying the passengers' discontent without revealing any recovery progress and if the employees fail to honestly describe the recovery situation and satisfy customer needs, they will lower customer satisfaction. Therefore, airlines must train and educate employees concerning their direct responses.

Concerning the items for s problem solving efficiency, the results showed that the item 'ability to promptly answer my questions' achieved the highest score whereas the item 'the service recovery time was longer than what I expected' achieved the lowest score. 
This finding indicated that regardless of industry, all customers demand high service recovery efficiency. Therefore, when flight delays occur, employees must answer the passengers' questions quickly and inform them of the recovery progress to minimize customer discontent. Superior service recovery efficiency will improve post-recovery satisfaction and project a positive image of the airlines, thereby increasing traveler repurchase intentions.

\subsection{Study Limitations \& Recommendations}

There are some limitations in this study. First, the sample of the study is limited to airline passengers at Kaohsiung international airport in Taiwan so the results might not be generalized. Replicating similar studies at other airports even other service industry would help to increase the generalizability of the findings.

The second limitation is the sampling type and size. Since service failure is not a common occurrence for every passenger, it is hard to recognize a sufficient number of airline service failures for taking a random sample of the population. Consequently, a convenience sampling method was used for this study and therefore the results might not be generalized.

The punctuality of flight operations is essential to both airlines and passengers. When facing a flight delay or cancellation, most passengers will have no choice but to cancel or change their itinerary. When service failure occurs, airlines must emphasize the relevant recovery measures and incorporate the recommendations made by passengers as a part of the recovery measures, thereby enabling the customers to feel respected and improving their satisfaction with airlines. The frontline employee skills training and development of a customer-oriented employee attitude are also crucial. If frontline employees are able to take the initiative and explain the cause of service failure, offer timely customer care, and provide customers with a clear understanding of the recovery progress, they will eliminate potential customer anxiety and anger caused by confusion. In addition, high service recovery efficiency can reduce the time required to recover a service failure (e.g., flight delay).

\section{REFERENCES}

- Cheng, S.-C. (2002), 'The Satisfactory Determinants of Service Recovery Quality: An Exploratory Study', Management Review, 21(3), 49-68.

- Bamford, D. and Xystouri, T. (2005), 'A case study of service failure and recovery within an international airline', Managing Service Quality, 15(3), 306-322. 
- Bitner, M. J., Booms, B. H. \& Tetreault, M. S. (1990), 'The service encounter: Diagnosing favorable and unfavorable incidents', Journal of Marketing, 54(1), 71-85.

- Boshoff, C. (1997), 'An experimental study of service recovery options', International Journal of Service Industry Management, 8(2), 110-130.

- Churchill, G. A., Jr. \& Surprenant, C. (1982), 'An investigation into the determinants of customer satisfaction', Journal of Marketing Research, 19(11), 491-504.

- Craighead, C. W., Karwan, K. R. \& Miller, J. L. (2004), 'the Effects of Severity of Failure and Customer Loyalty on Service Recovery Strategies', Production and Operations Management, 13(4), 307-321.

- Fisk, R. P., Brown, S. W. \& Bitner, M. J. (1993), 'Tracking the Evolution of the Services Marketing Literature', Journal of Retailing, 69 (1), 61-103.

- Hart, C. W. L., Heskett, J. L., \& Sasser, W. E., Jr. (1990), 'The profitable art of service recovery', Harward Business Review, 68(4), 148-156.

- Johnston, T. C. \& Hewa, M. A. (1997), 'Fixing service failures', Industrial Marketing Management, 26(5), 467-473.

- Lapre, M.A. (2011), 'Reducing Customer Dissatisfaction: How Important Is Learning to Reduce Service Failure?', Production and Operations Management, 20(4), 491-507.

- Liao, H. (2007). Do it right this time: the role of employee service recovery performance in customer-perceived justice and customer loyalty after service failures. Journal of applied psychology, 92(2), 475-489.

- Maxham III, J. G. (2001), 'Service recovery's influence on consumer satisfaction, positive word-of-mouth, and purchase intentions', Journal of Business Research, 54(1), 11-24.

- McCollough, M. A., Berry, L. L. \& Yadav, M. S. (2000), 'An empirical investigation of customer satisfaction after service failure and recovery', Journal of Service Research, 3(2), 121-131.

- Oliver, R. L. (1981), 'Measurement and evaluation of satisfaction process in retail settings', Journal of Retailing, 57(3), 25-48.

- Oliver, R. L., \& DeSarbo, W. S. (1988), 'Response determinants in satisfaction judgments', Journal of Consumer Research, 14(4), 495-507.

- Schoefer, K. and Ennew, C. (2004), 'Customer evaluations of tour operators' responses to their complaints', Journal of Travel and Tourism Marketing, 17(1), 83-92.

- Steyn, T., Mostert, P., De Meyer, C., \& van Rensburg, L. (2011), 'The effect of service failure and recovery on airline-passenger relationships: a comparison between South African and United States airline passengers', Journal of Management Policy and Practice, 12(5), 105-115.

- Weber, K., \& Sparks, B. (2010), 'Service Failure and Recovery in a Strategic Airline Alliance Context: Interplay of Locus of Service Failure and Social Identity', Journal of Travel \& Tourism Marketing, 27(6), 547-564.

- Wen, B., \& Chi, C. (2013). 'Examine the cognitive and affective antecedents to service recovery satisfaction: A field study of delayed airline passengers'. International Journal of Contemporary Hospitality Management, 25(3), 306-327.

- Wirtz, J., \& Mattila, A. S. (2004). 'Consumer responses to compensation, speed of recovery and apology after a service failure'. International Journal of Service Industry Management, 15(2), 150-166.

- Xu, X., \& Li, Y. (2016), 'Examining Key Drivers of Traveler Dissatisfaction with Airline Service Failures: A Text Mining Approach', Journal of Supply Chain and Operations Management, 14(1), 30-50.

- Zeelenberg, M., Pieters, R. (2004), 'Beyond Valence in Customer Dissatisfaction: A Review and New Findings on Behavioral Responses to Regret and Disappointment in Failed Services', Journal of Business Research, 57(4), 445-455. 